\title{
REVISION OF THE GENUS XERULA MAIRE (BASIDIOMYCETES, AGARICALES) IN POLAND
}

\author{
ANNA RONIKIER \\ W. Szafer Institute of Botany, Polish Academy of Sciences \\ Lubicz 46, 31-512 Cracow, Poland \\ e-mail: A.Ronikier@ib-pan.krakow.pl \\ (Received: February 27, 2003. Accepted: October 10, 2003)
}

\begin{abstract}
Data concerning morphology, ecology and distribution of Polish representatives of the genus Xerula Maire are discussed in the paper. All available specimens of X. pudens and X. melanotricha from Polish herbaria were reexamined to verify their identity and geographical distribution. Several new localities of $X$. melanotricha in the country are provided. A key to European taxa of the genus is proposed.
\end{abstract}

KEY WORDS: Xerula, X. melanotricha, X. pudens, Basidiomycetes, Agaricales, Poland, distribution, morphology, ecology.

\section{INTRODUCTION}

The genus Xerula Maire is represented in Europe by 6 species, which have the following common characters: fruitbody collybioid; cap gray, brown to black, dry or viscid, glabrous or villose; gills white, distant, broad; stem erect, rooting, glabrous or villose; spore-print white, spores hyaline globose to subglobose or broadly ellipsoid, smooth or with big spines, non-amyloid; pleurocystydia and cheilocystidia present; cap cuticle hymeniderm. In most species cap and stem is covered with hyaline hairs or yellow-brown to blackish-brown macrosetae.

Three species of the genus are present in Poland. Xerula radicata (Relhan: Fr.) Dörfelt is the most common among them (as it is in whole Europe). X. pudens (Pers.) Sing. has been reported from several localities in the country. In Europe this species is connected with oak. Only two localities of the third one, $X$. melanotricha Dörfelt, have been published in Poland so far. This species occurs on calcareous soils and accompanies fir.

The aim of the present work is to analyze the taxonomy and distribution of the genus Xerula in Poland. All available herbarium materials and literature data concerning this genus in Poland were critically revised. It allowed an exhaustive discussion on the presence and frequency of these taxa in the country. Additionally, a key to European species of the genus is provided.

\section{MATERIAL AND METHODS}

Revision of herbarium materials of $X$. pudens and X. melanotricha from Polish herbaria (KRAM-F, KRA, KTC,
LBLM, LOD, POZM, WA, WRSL, ZAMU) was done to verify their identity, presence and distribution in Poland. The note about distribution of $X$. radicata is based on literature data (for detailed map of distribution see: Ronikier $2004 c$, in press). The description of species and drawings refer to Polish collections. The key to European species is based on other keys from European countries (Knudsen 1992; Bas et al. 1999), works by Dörfelt (1979, 1980a, b), Boekhout and Bas (1986) and author's own observations.

\section{RESULTS}

\section{Key to the European taxa of Xerula}

Among six European species of Xerula the three, which have not been found in Poland so far, are rare or very rare in Europe, but regarding their habitats, they are likely to occur in the country. $X$. caussei Maire grows in beech forests on calcareous bedrock and it was reported from several countries in Western Europe; the locality from eastern part of Germany (Dörfelt 1973) is the closest to Poland, where it could be found in calcareous parts of the Carpathians. X. xeruloides (Bon) Dörfelt occurs in sandy habitats, so it is likely to be found in coastal areas of Poland. $X$. kuehneri (Romagn.) Bas et Boekhout is the rarest and the smallest species of the genus and it grows solitarily, therefore its basidiocarps are difficult to spot.

The key to European species of Xerula provided below, is based on the most distinctive and the easiest to observe features (in author's opinion). For full descriptions of taxa absent in Poland see: X. kuehneri and X. caussei (Boekhout, Bas 1986), X. xeruloides (Bon 1975; Dörfelt 1980a). 
1. Cap glabrous, dry or viscid $X$. radicata

1.* Cap tomentose, covered with hairs or macrosetae ...... 2

2. Hairs hyaline ........................................................... 3

2. * Hairs (macrosetae) coloured ....................................... 5

3. Spores with subcylindrical to conical spines ... X. kuehneri 3.* Spores smooth ............................................................ 4

4. Hairs non-septate ..X $X$. caussei $(=X$. nigra Dörfelt, $=X$. renati Clemençon)

4.* Hairs septate X. xeruloides

5. Hairs (macrosetae) up to $3 \mathrm{~mm}$ long, cystidia thin or slightly thick-walled (walls up to $1 \mu \mathrm{m}$ thick), incrusted on the top, incrustation soluble in $5 \% \mathrm{KOH} \ldots . . . X$. melanotricha

5.* Hairs (macrosetae) about $1 \mathrm{~mm}$ long, cystidia thickwalled (walls 2-5 $\mu \mathrm{m}$ thick), incrusted on the top, incrustation not soluble in $5 \% \mathrm{KOH}$

6. Hairs dark, chocolate-brown, red-brown ....... X. pudens var. fusca

6.* Hairs golden-yellow, golden-brown ......X. pudens var. pudens

Review of the genus Xerula in Poland

Xerula radicata (Relhan: Fr.) Dörfelt

Synonyms: Oudemansiella pseudoradicata M.M. Moser, $O$. radicata (Relhan: Fr.) Singer.

Cap plano-convex 3-7 cm diam., pale yellowish to ochraceous-brown, shiny, glabrous, radially rugose, slightly viscid. Lamellae white, distant, adnate, broad, edge whitish, ciliate. Stipe $10-15 \times 0.5-0.8 \mathrm{~cm}$, pale yellowish-brown, cylindrical, longitudinally grooved, with slightly thickened base and tapering root. Flesh whitish, smell and taste none.

Pleurocystidia scattered, 78-105 × 19-30 $\mu \mathrm{m}$, thin-walled, clavate, often with obtuse or truncate apex. Cheilocystidia similar to pleurocystidia. Pileipellis hymeniderm, consists of clavate cells $30-50 \times 14-30 \mu \mathrm{m}$ with brown intracellular pigment. Basidia 4-spored, 50-65 × 10-15 $\mu \mathrm{m}$. Spores broadly elliptic 13-16 × 9-11 $\mu \mathrm{m}$, hyaline, nonamyloid (Fig. 1).

Remarks: The species is very variable as concerns colours, shape of cystidia and structure of pileipellis. Several varieties were described (see Dörfelt 1983). The revision of all Polish materials is needed to verify their presence in the country. $X$. radicata is present on many scattered localities in Poland (Ronikier 2004c, in press), and it is a common species.

Specimen examined: Poland. Centralne Karpaty Zachodnie mts.: Tatry Zachodnie mts. Sarnia Skała massif, Grześkówki ridge (1956’35'E, 49¹6’36”N), Dentario glandulosae-Fagetum, on soil, at dead standing stem of Fagus sylvatica, ca 960 m., 20 May 2000, leg. A. Ronikier (KRAM F-39928).

Xerula pudens (Pers.) Sing.

Synonyms: Xerula longipes (Bull.) Maire, Oudemansiella badia (Quél.) M.M. Moser ss. Moser, Oudemansiella longipes (Bull.) M.M. Moser.

Cap young convex with incurved margin, later campanulate, convex with a broad umbo, then expanded, sometimes slightly depressed in the center, $1.5-11 \mathrm{~cm}$ diam., brown, foxy-brown, yellowish-brown, cream-foxy to grayishbrown sometimes with olive tint, velvety-tomentose, covered with golden-foxy hairs (macrosetae). Margin even to inrolled, setose. Lamellae white to cream-coloured, waxy,

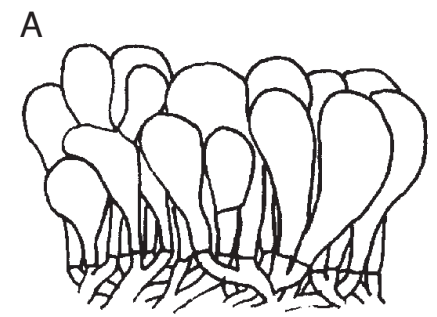

B

C
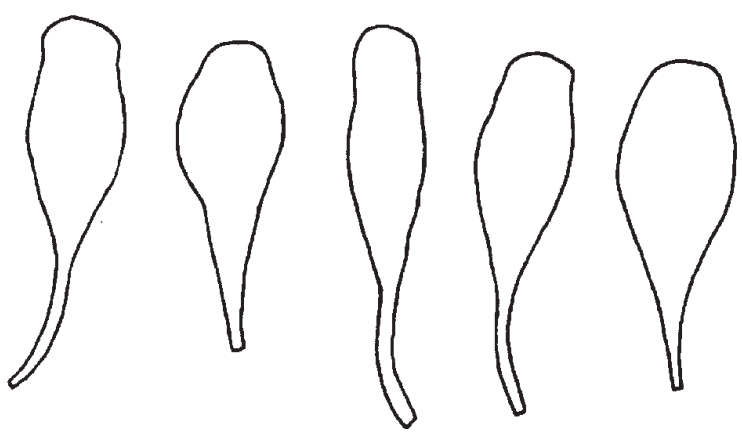

Fig. 1. Xerula radicata (Relhan: Fr.) Dörfelt: A - Pileipellis, B - Spores, C - Pleurocystidia; bar $=20 \mu \mathrm{m}$.

moderately thick, distant, narrowly adnate, broad, edge smooth. In one collection from Stary Rachów (LBLM, sine num.) thick-walled macrosetae are present in the hymenium. Stipe $12-15 \times 0.4-1 \mathrm{~cm}$, yellow-brown, grayishbrown, cylindric to slightly clavate, longitudinally grooved, often twisted, with root up to $7 \mathrm{~cm}$ long, tomentose, covered with golden-foxy hairs. Flesh thick, whitish to cream-coloured, smell faint, taste mild or slightly bitterish (recorded by a collector in specimen from Stary Rachów).

Cheilocystidia abundant, 100-120 × 13-25 $\mu \mathrm{m}$, lageniform, thick-walled, walls sometimes yellowish, with crystals on the top. Cristals not soluble in $5 \% \mathrm{KOH}$. Pleurocystidia numerous, similar to cheilocystidia, 105-135 × 25-37 $\mu \mathrm{m}$. Pileipellis hymeniderm, consists of clavate to vesicular cells $25-70 \times 15-30 \mu \mathrm{m}$ with brown intracellular pigment. Hairs acute, thick walled, about $1000 \times 10-20 \mu \mathrm{m}$, walls 2 $-5 \mu \mathrm{m}$ thick. Basidia 4-spored, 50-70 × 10-12 $\mu \mathrm{m}$. Spores globose to subglobose 10-11 × 8-10 $\mu \mathrm{m}$, hyaline, non-amyloid (Fig. 2).

Remarks: Two varieties of $X$. pudens have been distinguished (Dörfelt 1980a): var. pudens - the typical one, and var. fusca characterized by darker setae. Only var. pudens is present in Poland. According to Dörfelt (1980a) the distribution of var. fusca is limited to S-W Europe.

As the species is connected to Quercus in Europe, its distribution in Poland could theoretically cover the whole area of the country besides higher parts of the mountains, where oak is not present (Zając A., Zając M. 2001). Based on data available, however, the fungus seems to be rare in Poland, recorded on scattered localities, only locally more common (Ronikier 2004a, in press).

Specimens examined: Poland. Pojezierza Południowobałtyckie lakelands: Pojezierze Chodzieżskie lakeland, Wągrowiec district, Durowo forestry, „Dębina” nature reserve, forest division no. 147, Galio-Carpinetum corydaletosum, on oak roots, 16 Sept. 1995, leg. M. Połczyńska (POZM, sine num., Lisiewska, Połczyńska 1998); „Dębi- 


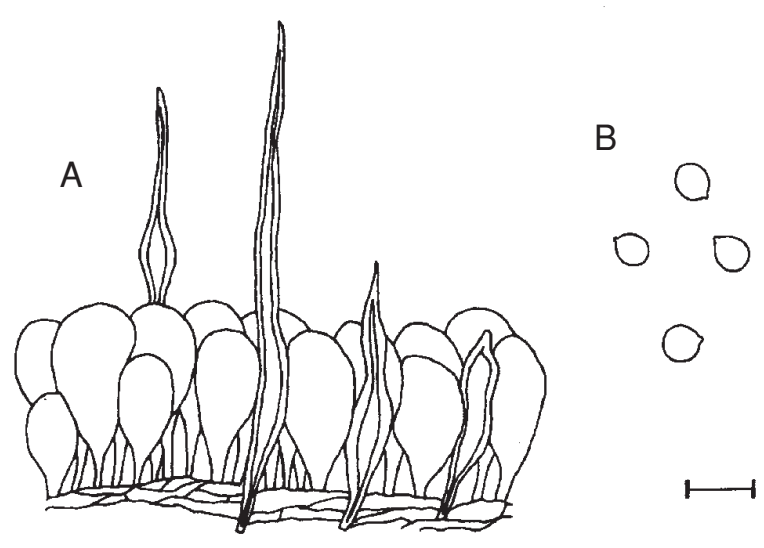

C
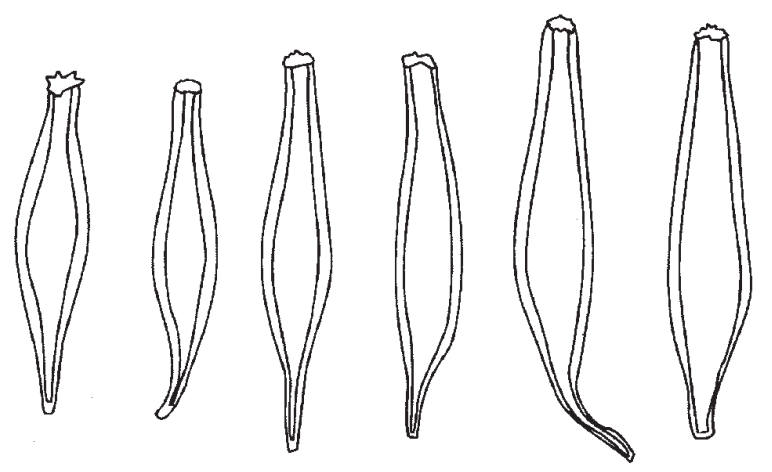

Fig. 2. Xerula pudens (Pers.) Sing.: A - Pileipellis, B - Spores, C - Pleurocystidia; bar $=20 \mu \mathrm{m}$.

na" nature reserve, Querco-Carpinetum corydaletosum at the base of trunk, 25 Aug. 1961, leg. M. Lisiewska (POZM, sine num., - as Oudemansiella badia (Lucand), Lisiewska 1965); „Dębina” nature reserve, Querco-Carpinetum stachyetosum silvaticae, at the bottom of decayed trunk, 31 Aug. 1960, leg. M. Lisiewska (POZM, sine num., - as Oudemansiella badia, Lisiewska 1965); Pojezierze Stęszewskie lakeland, Wielkopolski National Park, near Puszczykowo, at Jezioro Góreckie lake, Querceto-Carpinetum, on soil, 5 Sept. 1957, leg. M. Lisiewska (POZM, sine num., Lisiewska 1961); Brda River valley, Bory Tucholskie region, "Piekiełko" (about $5 \mathrm{~km}$ SSW of Tuchola), Tilio-Carpinetum, on soil, among litter, at a trunk, 31 Aug. 1994, leg. T. Dziedziński (LOD 14595, Ławrynowicz et al. 2003, in press); Niziny Środkowopolskie lowlands: Wzgórza Dalkowskie hills, Głogów forestry, „Uroczysko Obiszów" nature reserve, forest division no. 149, Galio silvatici-Carpinetum typicum, on oak root, 22 Aug. 1994, leg. W. Sekuła-Woźniak (POZM, sine num., Lisiewska, Sekuła-Woźniak 1998); Równina Warszawska plain, Warsaw-Bielany, Lasek Bielański forest, oak-hornbeam forest with Quercus robur and Pinus sylvestris, 28 Sept. 1958, leg. W. Rudnicka (WA 12542, Rudnicka 1960); Pradolina Wrocławska proglacial valley, Wrocław-Osobowice (Breslau-Oswitz), (WRSL, sine num., Schroeter 1885-1889). Wyżyna Śląsko-Krakowska upland: Wyżyna Olkuska upland, Ojcowski National Park, Pieskowa Skała, about 1 km NW of the castle in Pieskowa Skała, near Kołowrocie rocks, Pino-Quercetum variant with Pinus, 16 Sept. 1961, leg. W. Wojewoda (KRAM F-52679, Wojewoda 1974); Wyżyna Czę- stochowska upland, Mstów, communal forest, on roots of deciduous trees, 28 Sept. 1996, leg. E. Kowalczyk, (LOD 16003, Kowalczyk 1997); 80-years old oak forest, at the trunk, 22 Aug. 1996, leg. M. Ławrynowicz (LOD 17750, Ławrynowicz 2001); Góra 3 Maja hill, Mstów, oak forest, at the oak trunk, 23 July 1996, leg. K. Salamon (LOD 16249); 6 Sept. 1995, leg. K. Salamon (LOD 16250, Salamon 1997); Wyżyna Wieluńska upland, Dobra hill near Mstów, on the wood covered by soil, 7 July 1995, leg. A. Tolak (LOD 15955); 22 July 1996, leg. A. Tolak (LOD 15956, Tolak 1997); Wyżyna Małopolska upland: Góry Świętokrzyskie mts., Korzecko near Chęciny, Grzywy Korzeckie hills, forest division no. 189, Potentillo albae-Quercetum, on soil, 30 Oct. 1994, leg. J. Łuszczyński (KTC B485, Łuszczyński 1998). Wyżyna Lwowska upland: Wzniesienia Urzędowskie elevations, Stary Rachów near Annopol, on trees' roots, in oak-hornbeam forest, on chalky soil, 10 Sept. 1965, leg. B. Sałata (LBLM, sine num., Sałata 1968); Północne Podkarpacie region: Nizina Nadwiślańska lowland, Puszcza Niepołomicka forest, forest division no. 447, between Chobot and Ispina, about 30 $\mathrm{km}$ E from the center of Cracow, Tilio-Carpinetum, 30 Aug. 1995, leg. Z. Heinrich (KRAM F-36394, Wojewoda et al. 1999); Puszcza Niepołomicka forest, forest division no. 460, „Lipówka” nature reserve, about $2 \mathrm{~km} \mathrm{NE}$ from Chobot, Tilio-Carpinetum, 3 Oct. 1988, leg. Z. Heinrich and E. Kot (KRAM F-29073); 20 Oct. 1989, leg. W. Wojewoda (KRAM F-52678); Puszcza Niepołomicka forest, forest division no. 426, between Chobot and Ispina, „Koło” nature reserve, Tilio-Carpinetum, 17 Sept. 1981, leg. H. Komorowska (KRAM F-25991, Komorowska 1991); Puszcza Niepołomicka forest, forest division no. 431, 15 Sept. 1983, leg. B. Godzik (KRAM F-52683, Komorowska 1991); Pomost Krakowski region, Cracow, Wzgórza Tynieckie hills, ,Skołczanka” nature reserve, deciduous forest (Tilio-Carpinetum), 25 Aug. 1990, leg. B. Gumińska, (KRA, sine num., Gumińska 1991-1992); Wzgórza Tynieckie hills, Sidzińska Góra hill, mixed forest (Carpinus, Quercus), 11 Oct. 1998, leg. W. Wojewoda (KRAM F-52815); Cracow, Las Wolski forest, about $0.5 \mathrm{~km}$ W from Astronomical Observatory of Jagiellonian University, edge of the forest, at the trunk of deciduous tree ?Quercus, 29 Aug. 1987, leg. W. Wojewoda (KRAM F-52858, Wojewoda 1996).

Specimens misidentified:

1. Oudemansiella longipes - Pojezierze Poznańskie lakeland, Nowy Tomyśl district, Urbanowo, QuercetoCarpinetum lathyretosum verni variant with Betula, on soil, 22 Aug. 1960, leg. H. Bujakiewicz (POZM, sine num.); (Bujakiewicz, Fiklewicz 1963) = Melanoleuca stridula (Fr.) Métrod,

2. Oudemansiella longipes - Płaskowyż Nałęczowski plateau, Lublin, Botanical Garden in Sławinek, 9 Sept.1976, leg. Jolanta Lupa-Grzegorczyk (LBLM, sine num.); (?Flisińska 1984) = Flammulina velutipes $($ Curtis) Singer.

\section{Xerula melanotricha Dörfelt}

Cap young campanulate, later convex with a broad umbo, then plane to concave, 1-6 cm diam., chocolatebrown, grayish-brown, blackish-brown, more rarely yellowish-brown, velvety-tomentose, covered with dark brown to blackish-brown, long hairs (macrosetae). Sometimes two 
distinct color zones are visible: yellowish-brown at the center of cap and chocolate-dark brown at the margin. The zones remain visible also in dry specimens. Margin of cap incurved, then even, villose-setose. Lamellae white, waxy, moderately thick, distant, broad, narrowly adnate, edge smooth. Stipe $4-13 \times 0.2-0.7 \mathrm{~cm}$, concolourous with cap, cylindric to clavate, often with strongly thickened base up to $1.5 \mathrm{~cm}$ diam. and tapering root $4-12 \mathrm{~cm}$ long, longitudinally grooved, often twisted. Whole stem covered with brown to blackish-brown hairs. Flesh thick, whitish, smell faint, taste mild.

Cheilocystidia scattered, 100-125 × 20-30 $\mu \mathrm{m}$, ventricose, fusiform, slightly thick-walled (wall up to $1 \mu \mathrm{m}$ ), some slightly incrusted or with ?amorphous substance on the apex (incrustation soluble in 5\% KOH). Pleurocystidia more numerous, similar to cheilocystidia, $75-130 \times 22-45 \mu \mathrm{m}$. Pileipellis hymeniderm, consists of clavate to vesicular cells 30-85 $\times 12-35 \mu \mathrm{m}$ with brown intracellular pigment. Hairs thick-walled 80-2900 × 15-29 $\mu \mathrm{m}$, walls 2-4 $\mu \mathrm{m}$ thick. Basidia 4-spored, 26-55 × 10-15 $\mu \mathrm{m}$. Spores globose to subglobose $10-11.5 \times 8-11 \mu \mathrm{m}$, hyaline, non-amyloid (Fig. 3).

Remarks: The species was not recognized in Poland before. Only two localities are known from the literature (Szczepka, Sokół 1986; Łuszczyński 2002). The revision of herbarium material changed completely the view on occurrence of the species in this part of its distribution. The fungus occurs within the distribution area of fir (see Zając A., Zając M. 2001), in calcareous regions, and it can be considered as locally common (Ronikier 2004b, in press). The northern limit of its distribution range crosses the country.
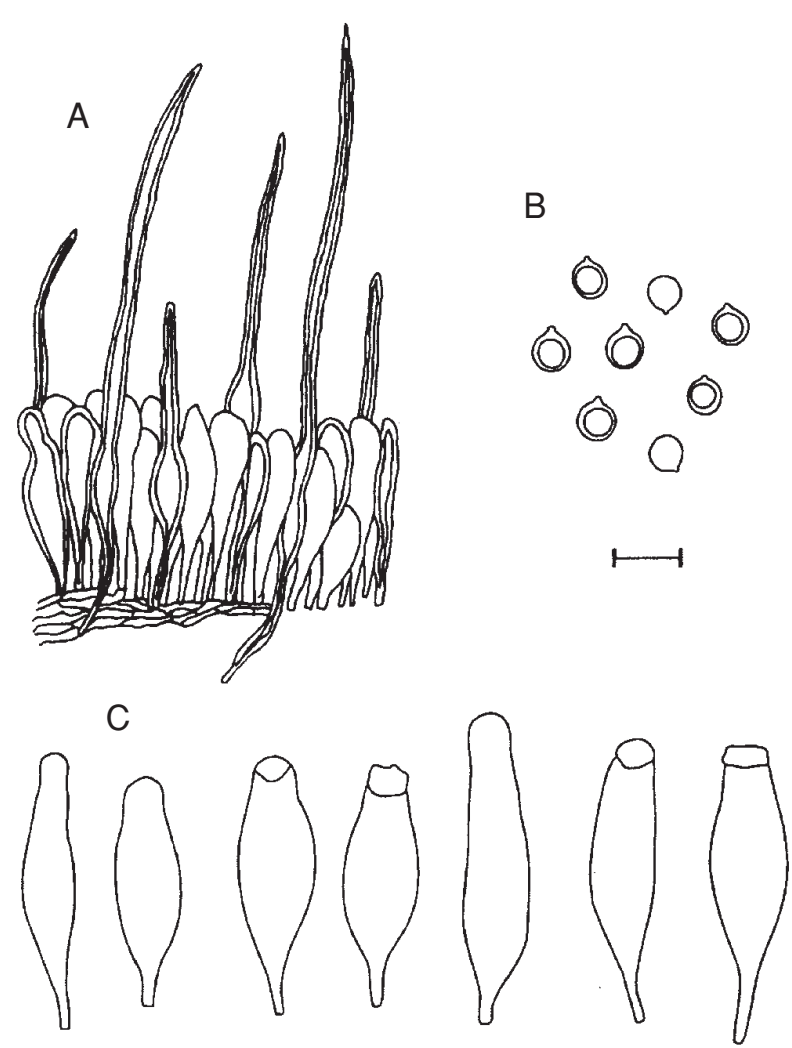

Fig. 3. Xerula melanotricha Dörfelt: A - Pileipellis, B - Spores, C - Pleurocystidia; bar $=20 \mu \mathrm{m}$.
Specimens examined: Poland. Niziny Środkowopolskie lowlands: Wysoczyzna Złoczewska high plain, Złoczew forestry, „Nowa Wieś” nature reserve, 7 May 1996, leg. J. Makowczyńska (LOD 17760) - as X. pudens (Pers.) Sing (Makowczyńska 1997); Wyżyna Śląsko-Krakowska upland: Wyżyna Olkuska upland, Ojcowski National Park, Złota Góra hill, Pino-Quercetum, variant with Fagus, 10 Aug. 1966, leg. W. Wojewoda (KRA, sine num.) - as $O$. longipes (Bull. ex St-Am.) Mos. (Wojewoda 1974); small valley at the mouth of Jamki gully, near Sąspów valley, Fagetum carpaticum, 2 Aug. 1963, leg. R. Rejchelówna (KRA, sine num.) - as O. longipes (Wojewoda 1974); Złota Góra hill, 30 Aug. 1960, leg. W. Wojewoda (KRAM F-52666) - as O. longipes (Wojewoda 1974); Złota Góra hill, SW slopes, Pino-Quercetum variant with Fagus sylvatica, 27 July 1961 (KRAM F-52667) - as O. longipes (Wojewoda 1974); at the bottom of Złota Góra hill, above Prądnik valley, about $300 \mathrm{~m} \mathrm{SW}$ from the castle ruins in Ojców, fragments of Pino-Quercetum variant with Abies alba and Tilio-Carpinetum, 17 Aug. 1961, leg. W. Wojewoda (KRAM F-52669, KRAM F-52674) - as O. longipes (Wojewoda 1974); Złota Góra hill, above Błotny Dół gully, fragments of Fagetum carpaticum collinum and Pino-Quercetum variant with Fagus sylvatica, 9. Aug. 1963, leg. W. Wojewoda (KRAM F-52671) - as O. longipes (Wojewoda 1974); Złota Góra hill, about $0.5 \mathrm{~km}$ NW from the castle ruins in Ojców, 20 Sept. 1962, leg. W. Wojewoda (KRAM F-52672) - as O. longipes (Wojewoda 1974); at the bottom of Złota Góra hill, near the mouth of Sąspówka stream, Tilio-Carpinetum, 13 July 1963, leg. W. Wojewoda (KRAM F-52675) - as O. longipes (Wojewoda 1974); vicinity of Pochylce and Łamańce rocks, at the fork of the road Kraków-Olkusz to Skała, 12 Oct.?1961, leg. W. Wojewoda (KRAM F-52676) - as O. longipes (Wojewoda 1974); Chełmowa Góra hill, Fagetum carpaticum collinum variant with Asperula odorata and Majanthemum bifolium, 27 Sept. 1967, leg. W. Wojewoda (KRAM F-52668) - as $O$. longipes (Wojewoda 1974); Chełmowa Góra hill, near the top, Fagetum carpaticum, 11 Aug. 1961, leg. W. Wojewoda (KRA, sine num.) - as O. longipes (Wojewoda 1974); the top of Chełmowa Góra hill, 14 Sept. 1961, leg. W. Wojewoda (KRAM F-52670) - as O. longipes (Wojewoda 1974); Góra Okopy hill, Tilio-Carpinetum, under Abies alba, 14 Sept. 1967, leg. W. Wojewoda (KRAM F-52673) - as O. longipes (Wojewoda 1974); Chełmowa Góra, about $200 \mathrm{~m}$ from the mouth of Sąspówka stream, 26 Aug. 1961, leg. W. Wojewoda (KRAM F-52677) - as O. longipes (Wojewoda 1974); Zewnętrzne Karpaty Zachodnie mts.: Pogórze Śląskie foothils, „Zadni Gaj” nature reserve, between Leszna Górna and Cisownica, near a stump of Abies alba, on calcareous bedrock, near the skirt of forest (Picea abies, Taxus baccata), ca 500 m., 17 July 1982, leg. S. Sokół (KRAM F-29564, Sokół, Szczepka 1986); Beskid Sądecki mts., Góra Kopciowa mt., near Krynica, fir forest, 22 Sept. 1962, leg. B. Gumińska (KRA, sine num.) - as $O$. longipes (Gumińska 1966); Centralne Karpaty Zachodnie mts.: Pieniny mts., Pieniny National Park, Ociemny Żleb gully, beech forest, 9 Aug. 1970, leg. E. Łagowska (KRA, sine num.); Pieniny mts., above Ociemny Potok stream, beech forest, 27 Sept. 1970, leg. B. Gumińska (KRA, sine num.); Pieniny mts., Bajków Groń meadow, above Pieniński Potok stream, beech forest, 10 Sept. 1969, leg. B. Gumińska (KRA, sine num.); Pieniny mts., at yel- 
low hiking trail, below place called „Istebki”, near Bajków Gron meadow, the edge of forest, 22 Sept. 1996, leg. A. Drozdowicz (KRA, sine num.); Pieniny mts., slopes of Góra Zamkowa mt., Fagetum carpaticum, 27 Aug. 1987, leg. B. Gumińska (KRA, sine num.); Pieniny mts., slopes of Czertezik mt., 18 Sept. 1970, leg. B. Gumińska (KRA, sine num.); Pieniny mts., between Białe Skały rocks and Czertezik mt., 15 Sept. 1987, leg. B. Gumińska (KRA, sine num.); Pieniny mts., under Kórnikowa Skała rock, beech forest, 6 Sept.1965, leg. B. Gumińska (KRA, sine num.) as $O$. badia (Lucand) (Gumińska 1969); Pieniny mts., upstream of Głęboki Potok, fir-spruce forest, 24 June 1967, leg. B. Gumińska (KRA, sine num.); Western Tatra mts. Sarnia Skała massif, Grześkówki ridge (1956’35”E, $\left.49^{\circ} 16^{\prime} 36^{\prime \prime} \mathrm{N}\right)$, Dentario glandulosae-Fagetum, on soil, at dead standing trunk of ?Abies, ca 960 m., 9 June 2000, leg. A. Ronikier (KRAM F-39960); Western Tatra mts. Sarnia Skała massif, western slope of Grześkówki ridge (1956'27'E, 49 16'37'N), Dentario glandulosae-Fagetum, on soil, ca 970 m., 16 Aug. 2003, leg. A. Ronikier (ZAMU B/97/MT-4358);

\section{DISCUSSION}

Most specimens of $X$. melanotricha collected in Poland were published under the names: Oudemansiella longipes or Oudemansiella badia, before the species was described by Dörfelt (1979); all these materials have not been reexamined later. Nevertheless, during 24 years after describing this taxon, only two localities were reported in Poland (Sokół, Szczepka 1986; Łuszczyński 2002).

At first look the two species of Xerula: X. pudens and X. melanotricha, are similar, especially without comparison to each other. But the differences between them are so clear, that the recognition is not difficult. Very long and almost black setae of $X$. melanotricha are usually easily visible by naked eye, while the setae of $X$. pudens look like tomentose cover on the pileus and stipe. In some younger specimens of $X$. melanotricha, however, the length of the hairs hardly exceed $1 \mathrm{~mm}$ and it is sometimes difficult to measure hairs on the cap; they are often broken in herbarium material. Still, the distinction between the two species is additionally facilitated by cystidia shape and thickness of their walls. X. melanotricha is characterized by wider cystidia with much thinner walls and incrustation on their apex soluble in $5 \% \mathrm{KOH}$, while $X$. pudens has thick-walled cystidia, very similar in shape to those of Inocybe, with incrustations not soluble in $\mathrm{KOH}$. Additionally, the number of pleuroand cheilocystidia is much bigger in case of $X$. pudens.

There are several localities of Agaricus longipes, Collybia longipes, Oudemansiella longipes or O. badia reported from Poland. The fungi are listed among other species without any information except the locality. As relevant herbarium materials have not survived or were not available, the material could not be examined. The stands not revised are:

1. Agaricus longipes Bull. - Łysica (Błoński 1890: 153)

2. Agaricus longipes Bull. - Węglowa Wólka near Warsaw (Błoński 1896: 85)

3. Agaricus longipes Bull. - vicinity of Międzyrzec Podlaski, forest of Żabiec? („Lasek Żabiecki” forest), Sept. (Eichler 1900: 198)
4. Collybia longipes Bull. - Dubeczno; Hańsk (Kwieciński 1896: 32)

5. Collybia longipes (Bull.) Quél. - Ojców valley (Yelenkin 1901: 20)

6. Collybia longipes Bull. - Poznań, Sołacki park, under oak trunk, 1.10.1928 (Teodorowicz 1933: 99)

7. Collybia longipes Bull. - Kwidzyn, "Liebenthaler Wald"; Mrągowo (Neuhoff 1933: 358)

8. Collybia longipes Bull. - Srebrna Góra, 19.09.1915. (Dittrich 1917: 7)

9. Oudemansiella longipes - Ojcowski National Park (Anonymous 1968: 193, Wojewoda 1966: 73)

10. Oudemansiella longipes (Bull. ex St. Am.) Moser - Zemborzyce near Lublin, pine forest, Sept.-Oct. (Flisińska 1996: 29)

11. Agaricus longipes Bull. - Góra (Guhrau: Oberwald), Central Poland Lowlands, Pradolina Wrocławska proglacial valley, Wrocław-Strachocin (Breslau-Strachate), Sudety Mts, Równina Świdnicka plain, Krasków near Świdnica (Schweidnitz, Kratzkau), (Schroeter 1885-1889: 647)

12. Oudemansiella badia (Quél.) Moser, O. longipes (Bull. ex Fr.) Bours. - Pojezierze Chodzieżskie lakeland, Wągrowiec, „Dębina” nature reserve, Querco-Carpinetum stachyetosum silvaticae, Querco-Carpinetum corydaletosum, Aug. 1960-1961 (Lisiewska 1961: 61; Lisiewska, Bujakiewicz 1976a: 124, b: 62)

13. Oudemansiella badia (Quél.) Moser, O. longipes (Bull.) Moser - Równina Bielska plain, Puszcza Białowieska primeval forest (Skirgiełło et al. 1992: 36, (Bujakiewicz 1997: 384, map F883)

14. Oudemansiella longipes (Bull. ex Fr.) Bours. - Wielkopolski National Park, Osowa Góra forestry, QuercoCarpinetum stachyetosum silvaticae, Sept. 1957; Opalenica, Urbanowo forestry, Querco-Carpinetum lathyretosum verni, Aug. 1960 (Lisiewska 1965: 249).

Localities mentioned above were not taken into account in preparing the distribution maps of $X$. melanotricha and $X$. pudens in Poland (Ronikier 2004a, b, in press). As most of that localities are situated in northern part of Poland, beyond the distribution of Abies alba (Zając A., Zając M. 2001), in all likelihood most of them refer to X. pudens.

Further field investigations are needed to complete the distribution map of representatives of Xerula in Poland, especially the two rare species: $X$. melanotrich $a$ and $X$. pudens.

\section{ACKNOWLEDGEMENTS}

My thanks are due to the curators of herbaria (KRA, KTC, LBLM, LOD, POZM, WA, WRSL, ZAMU) for loaning the specimens of Xerula spp., and to Dr. Wojciech Paul (Institute of Botany, Polish Academy of Sciences) for translation of fragments of papers by Dörfelt (1979-1983). This work was partly supported by grants no. 6P04G 043 21 and no. 6P04G 08320 from the State Committee for Scientific Research, Poland.

\section{LITERATURE CITED}

ANONYMOUS 1968. Compte-rendu du IV-ème Congrès des Mycologues Européens, Warszawa 1966. Acta Mycologica 4 (2): 181-198. 
BAS C., KUYPER T.W., NOORDELOOS M.E., VELLINGA E.C. (eds) 1999. Flora Agaricina Neerlandica. 4. Strophariaceae, Tricholomataceae (3). A.A. Balkema. Rotterdam. Brookfield, pp. 191.

BŁOŃSKI F. 1890. Wyniki poszukiwań florystycznych skrytokwiatowych dokonanych w ciągu lata r. 1889 w obrębie 5-ciu powiatów Królestwa Polskiego. Pamiętnik Fizjograficzny 10 (3): 129-190 (in Polish).

BŁOŃSKI F. 1896. Przyczynek do flory grzybów Polski. Pamiętnik Fizjograficzny 14 (3): 63-93 (in Polish).

BOEKHOUT T., BAS C. 1986. Notulae ad Floram Agaricinam Neerlandicam - XII. Some notes on the genera Oudemansiella and Xerula. Persoonia 13 (1): 45-56.

BON M. 1975. Agaricales rares ou nouvelles de la côte atlantique française. Documents Mycologiques 4 (17): 1-40.

BUJAKIEWICZ A. 1997. Agaricales. In: Cryptogamous plants in the forest communities of Białowieża National Park. Ecological Atlas. (Project CRYPTO 4). Faliński J.B., Mułenko W. (eds), Phytocoenosis N. S. 9 Suppl. Cartogr. Geobot. 7: 304-407.

BUJAKIEWICZ H., FIKLEWICZ G. 1963. Grzyby wyższe lasów dębowo-grabowych okolic Opalenicy (pow. Nowy Tomyśl, Wielkopolska). Badania Fizjograficzne nad Polską Zachodnią 12: 277-300 (in Polish with English summary).

DITTRICH G. 1917. Bemerkungen zu neuen Funden schlesischer Pilze. Hedwigia 58: 1-8.

DÖRFELT H. 1973. Oudemansiella nigra spec. nov. und ihre phytocönologische Beziehungen. Česká Mykologie 27: 27-32.

DÖRFELT H. 1979. Taxonomische Studien in der Gattung Xerula R. Mre. Feddes Repertorium 90 (5-6): 363-388.

DÖRFELT H. 1980a. Taxonomische Studien in der Gattung Xerula R. Mre. (II) Feddes Repertorium 91 (4): 209-223.

DÖRFELT H. 1980b. Taxonomische Studien in der Gattung Xerula R. Mre. (III) Feddes Repertorium 91 (7-8): 415-438.

DÖRFELT H. 1983. Taxonomische Studien in der Gattung Xerula R. Mre. (VI). Feddes Repertorium 94 (1-2): 43-85.

EICHLER B. 1900. Materiały do flory grzybów okolic Międzyrzeca. Pamiętnik Fizjograficzny 16 (3): 157-206 (in Polish).

FLISIŃSKA Z. 1984. Materiały do poznania flory grzybów wielkoowocnikowych (macromycetes) Lublina. Annales Universitatis Mariae Curie-Skłodowska 39: 9-18 (in Polish with English and Russian summary).

FLISIŃSKA Z. 1996. Studia nad grzybami wielkoowocnikowymi (macromycetes) Lublina. Annales Universitatis Mariae CurieSkłodowska 51: 13-39 (in Polish with English summary).

GUMIŃSKA B. 1966. Mikoflora lasów jodłowych okolic Muszyny. Acta Mycologica 2: 107-149 (in Polish with English summary).

GUMIŃSKA B. 1969. Mikoflora Pienińskiego Parku Narodowego. I. Acta Mycologica 5: 219-243 (in Polish with English summary).

GUMIŃSKA B. 1991-1992. Higher fungi of the Tilio-Carpinetum forest association in the Skołczanka reserve near Cracow. Acta Mycologica 27 (1): 137-158.

KNUDSEN H. 1992. Xerula Maire. In: Nordic macromycetes. 2. Polyporales, Boletales, Agaricales, Russulales, Hansen L., Knudsen H. (eds.), Nordsvamp, Copenhagen: 193.

KOMOROWSKA H. 1991 (1988). Tricholomataceae (Agaricales) Puszczy Niepołomickiej. Folia Societatis Scientiarum Lublinensis 30 (1-2): 55-62 (in Polish with English summary).

KOWALCZYK E. 1997. Badania grzybów w Lesie Komunalnym w Mstowie w latach 1994-1996. Diploma thesis, University of Łódź (unpublished work).

KWIECIŃSKI F. 1896. Roślinność gminy Hańsk powiatu włodawskiego. Pamiętnik Fizjograficzny 14 (3): 27-61 (in Polish).

LISIEWSKA M. 1961. Badania nad grzybami wyższymi w grądach Wielkopolskiego Parku Narodowego i Promna pod Poznaniem. Prace monograficzne nad przyrodą Wielkopolskiego Parku Narodowego pod Poznaniem 5 (1): 3-66 (in Polish with English summary).
LISIEWSKA M. 1965. Udział grzybów wyższych w grądach Wielkopolski. Acta Mycologica 1: 169-268 (in Polish with English summary).

LISIEWSKA M., BUJAKIEWICZ A. 1976a. Grzyby wyższe na tle zespołów leśnych. In: Roślinność rezerwatu „Dębina” pod Wągrowcem w Wielkopolsce, Wojterski T. (ed.), Badania Fizjograficzne nad Polską Zachodnią 29: 119-134 (in Polish with English summary).

LISIEWSKA M., BUJAKIEWICZ A. 1976b. Grzyby. In: Roślinność rezerwatu „Dębina” pod Wągrowcem w Wielkopolsce, Wojterski T. (ed.), Badania Fizjograficzne nad Polską Zachodnią 29: 57-67 (in Polish with English summary).

LISIEWSKA M., POŁCZYŃSKA M. 1998. Changes in macromycetes of the oak-hornbeam forests in the Dębina reserve (Northern Wielkopolska). Acta Mycologica 33 (2): 191-230.

LISIEWSKA M., SEKUŁA-WOŹNIAK W. 1998. Macrofungi of the oak forests in the "Uroczysko Obiszów" reserve (Głogów forest district). Badania Fizjograficzne nad Polską Zachodnią 47: 45-81

ŁAWRYNOWICZ M. 2001. Macromycetes of oak forests in the Jurassic Landscape Park (Częstochowa Upland) - monitoring studies. Acta Mycologica 36 (1): 81-110.

ŁAWRYNOWICZ M., DZIEDZIŃSKI T., SZKODZIK J. 2003. Rola diagnostyczna grzybów w zbiorowiskach roślinnych rezerwatu „Dolina Rzeki Brdy”. Materiały z V Konferencji „Bory Tucholskie - Ochrona Biosfery" (in press).

ŁUSZCZYŃSKI J. 1998. Macromycetes of the Potentillo albaeQuercetum in the Świętokrzyskie Mts. - monitoring studies. Acta Mycologica 33 (2): 231-245.

ŁUSZCZYNSKI J. 2002. The preliminary red list of Basidiomycetes in the Góry Świętokrzyskie Mts. Polish Botanical Journal 47 (2): 183-193.

MAKOWCZYNSKA J. 1997. Grzyby rezerwatu Nowa Wieś koło Złoczewa. Diploma thesis, University of Łódź (unpublished work).

NEUHOFF W. 1933. Die Hymenomyceten Ostpreussens. Eine systematische Zusammenstellung. Unser Ostland 2 (7): 319-397.

RONIKIER A. 2004a. Xerula pudens (Pers.) Sing. In: Atlas of the Geographical Distribution of Fungi in Poland, Wojewoda W. (ed.), W. Szafer Institute of Botany, Polish Academy of Sciences, Kraków, 3 (in press).

RONIKIER A. 2004b. Xerula melanotricha Dörfelt. In: Atlas of the Geographical Distribution of Fungi in Poland, Wojewoda W. (ed.), W. Szafer Institute of Botany, Polish Academy of Sciences, Kraków, 3 (in press).

RONIKIER A. 2004c. Xerula radicata (Relhan: Fr.) Dörfelt. In: Atlas of the Geographical Distribution of Fungi in Poland, Wojewoda W. (ed.), W. Szafer Institute of Botany, Polish Academy of Sciences, Kraków, 3 (in press).

RUDNICKA W. 1960. O kilku rzadkich grzybach z okolic Warszawy. Monographiae Botanicae 10 (2): 21-36 (in Polish with English summary).

SALAMON K. 1997. Grzyby Góry 3. Maja w Mstowie k. Częstochowy. Diploma thesis, University of Łódź (unpublished work).

SAŁATA B. 1968. Notatki mikologiczne z okolic Annopola. Acta Mycologica 4 (1): 53-70 (in Polish with German summary).

SCHROETER J. 1885-1889. Die Pilze Schlesiens. In: Kryptogamen Flora von Schlesien, Cohn F. (ed.), J. U. Kern's Verl. Breslau, pp. 814.

SKIRGIEŁŁO A., MUŁENKO W., SADOWSKA B. 1992. Fungi. In: Cryptogamous plants in the forest communities of Białowieża National Park, Faliński J., Mułenko W. (eds.), Phytocoenosis 4: 23-44.

SZCZEPKA M.Z., SOKÓŁ S. 1986. Rodzaj Xerula R. Maire w Polsce. I. Xerula melanotricha Dörfelt. Acta Biologica Silesiana, Botanika 4 (21): 156-165 (in Polish with English, German and Russian summaries).

TEODOROWICZ F. 1933. Grzyby zachodniej i południowej Polski w zbiorze Zakładu Botaniki Ogólnej Uniwersytetu Poznań- 
skiego. Wydawnictwo Okręgowego Komitetu Ochrony Przyrody na Wielkopolskę i Pomorze w Poznaniu 4: 1-34 (in Polish with English summary).

TOLAK A. 1997. Grzyby drzewostanu dębowego na Górze Dobrej w przełomie Warty. Diploma thesis, University of Łódź (unpublished work).

WOJEWODA W. 1966. Ojcowski National Park. In: Guide. Fourth Congress of European Mycologists. Poland, Warsaw, Skirgiełło A. (ed.): 71-73.

WOJEWODA W. 1974. Macromycetes Ojcowskiego Parku Narodowego. I. Flora. Acta Mycologica 10 (2): 181-265 (in Polish with English summary).
WOJEWODA W. 1996. Grzyby Krakowa w latach 1883-1994 ze szczególnym uwzględnieniem macromycetes. Studia Ośrodka Dokumentacji Fizjograficznej 24: 75-111 (in Polish with English summary).

WOJEWODA W., HEINRICH Z., KOMOROWSKA H. 1999. Macromycetes of oak-lime-hornbeam woods in the Niepołomice Forest near Kraków (S Poland) - monitoring studies. Acta Mycologica 34 (2): 201-266.

YELENKIN A. 1901. Flora Oycovskoy Doliny. Warszawa, pp. 167 (in Russian).

ZAJĄC A., ZAJĄC M. (eds) 2001. Distribution Atlas of Vascular Plants in Poland. Laboratory of Computer Chorology, Institute of Botany, Jagiellonian University, Cracow: 441-442.

\author{
REWIZJA RODZAJU XERULA MAIRE \\ (BASIDIOMYCETES, AGARICALES) W POLSCE
}

\title{
STRESZCZENIE
}

Rodzaj Xerula jest reprezentowany w Polsce przez trzy gatunki: X. radicata - gatunek pospolity, występujący na rozproszonych stanowiskach na terenie całego kraju, X. pudens - rzadszy gatunek przywiązany do dębu, występujący na kilkunastu stanowiskach w obrębie naturalnego zasięgu dębu, oraz X. melanotricha - gatunek towarzyszący jodle i występujący na podłożu wapiennym, podawany w Polsce dotychczas zaledwie z dwóch stanowisk. W niniejszej pracy prezentowane są dane na temat morfologii, ekologii i rozmieszczenia w Polsce gatunków z rodzaju Xerula. Wszystkie dostępne okazy X. melanotricha i X. pudens z polskich zielników (KRAM-F, KRA, KTC, LBLM, LOD, POZM, WA, WRSL, ZAMU) zostały zrewidowane; rewizja wykazała, że X. melanotricha występuje w Polsce co najmniej na kilkunastu stanowiskach. W pracy podano klucz do europejskich gatunków rodzaju Xerula.

SŁOWA KLUCZOWE: Xerula, X. melanotricha, X. pudens, Basidiomycetes, Agaricales, Polska, rozmieszczenie, morfologia, ekologia. 